\title{
Effect of wood betony (Stachys lavandulifolia Vahl) extract on some serum biochemical changes and acute stress response in juvenile common carp (Cyprinus carpio)
}

\author{
S Bahrami Babaheydari, S Dorafshan, F Paykan Heyrati and N Mahboobi Soofiani \\ Department of Natural Resources, Isfahan University of Technology, Isfahan, Iran
}

Received: March 2014

\begin{abstract}
The effects of four different levels of wood betony (WB) (Stachys lavandulifolia Vahl) extract (0, 2,4 and $8 \% \mathrm{~W} / \mathrm{W}$ in the diet) were investigated on some serum enzymatic activities and acute stress response of juvenile common carp (Cyprinus carpio). After 10 weeks post feeding, two groups of fish (0 and $8 \% \mathrm{WB}$ ) were subjected to handling and crowding stress and the stress responses including serum cortisol, glucose and some electrolytes $\left(\mathrm{Na}^{+}, \mathrm{K}^{+}\right.$ and $\mathrm{Ca}^{+2}$ ) levels were assayed. The results revealed that the fish fed on $8 \%$ WB had significantly lower levels of lactate dehydrogenase (LDH) and alanine transaminase (ALT) compared to the control group $(\mathrm{P}<0.05)$. Although cortisol and glucose levels were increased significantly shortly after stress $(\mathrm{P}<0.05)$, the elevation level was significantly lower for fish fed on $8 \%$ WB $(\mathrm{P}<0.05)$. In control group, sodium level decreased $(\mathrm{P}<0.05)$ at $3 \mathrm{~h}$ post stress but did not show any change in $8 \% \mathrm{WB}(\mathrm{P}>0.05)$. The potassium and calcium levels showed insignificant fluctuations post stress $(\mathrm{P}>0.05)$. Dietary inclusion of WB seems to improve liver function and response to acute stress in juvenile common carp.
\end{abstract}

Keywords: stress, enzyme activity, ion regulation, wood betony, common carp.

\section{Introduction}

Fish cultivation under intensive conditions has been

Correspondence S Dorafshan, Department of Natural Resources, Isfahan University of Technology, Isfahan, Iran (e-mail: sdorafshan@cc.iut.ac.ir)
Accepted: July 2014

increased all around the world. High rearing densities, poor water quality, weighing, transportation and grading are common stressors which can both affect fish welfare and increase the risk of disease under intensive fish cultivation. Different levels of stress reactions has been well-defined in fish including primary (hormonal response), secondary (metabolic and haematological changes) and tertiary as a last stage which leads to exhaustion, growth decline or death (Barton 2002). Urbinati \& Carnerio (2001) defined handling as a practice including chasing, capture and exposing the fish to air which can cause explicit physiological and endocrinological responses in fish. Dobšikova, Svobodova, Blahova, Modra \& Velišek (2006) observed that $12 \mathrm{~h}$ transportation could cause significant changes in some biochemical and haematological indices of three years old common carp. However, McCormick, Shrimpton, Carey, O’Dea, Sloan, Moriyama \& Björnsson (1988) found out that handling stress decreased growth rate of Atlantic salmon (Salmo salar). Different practices such as water quality optimization, optimal fish density and administration of natural or synthetic compounds could be used to improve fish resistance to stressor. Synthetic feed additives have some adverse effects such as bioaccumulation and environmental pollution. Due to these problems, much more attention has been focused on the use of medicinal plants in aquaculture (Citarasu 2010; Chakraborty $\&$ Hancz 2011). Most of the studies about the effect of using herbal biomedicine in aquaculture has been focused on their application such as growth promoter, immune stimulator or antipathogenic agent in different cultivated fish species like African catfish (Clarias gariepinus) (Dada \& Ikuerowo 2009; Soosean, Marimuthu \& Sudhakaran 2010), Tilapia 


\section{S Bahrami Babaheydari et al., Effect of wood betony extract on stress response in carp}

(Orechromis mossambicus) (Immanuel, Uma \& Iyapparaj 2009), common carp (Cyprinus carpio) (Alishahi, Ranjbar \& Ghorbanpour 2010; Pakravan, Hajimoradloo \& Ghorbani 2012) and olive flounder (Paralichthys olivaceus) (Cho \& Lee 2012). However, little information is available on the effects of herbs on stress responses in fish (Xie, Liu, Zhou, Su, He, Pan, Ge \& Xu 2008; Shahsavani, Baghshani \& Alishahi 2010). Wood betony (Stachys lavandulifolia Vahl) which has been belonged to family Lamiaceae, is grown in many parts of Iran, Turkey, Iraq, Syria, Armenia as well as Georgia (Javidnia, Mojab \& Mojahedic 2004). Fresh and dried areal parts such as leaves, flowers and roots have been used as traditional drugs for treatment of wounds and bruises, mouth ulcers, gum inflammations (Ody 1997) as well as treating arthritis and respiratory inflammatory disorders (Rezazadeh, Zaringhalam, Manaheji \& Kebryaeezadeh 2009). Alkanoids (including stachydrine and trigonelline), tannins, saponines, nicotinic acid, polyphenols, organosulfids and steroids are the main components of wood betony (Vundac, Brantner \& Plazibat 2007). Some of the Stachys components' have shown a variety of biological activities (Chakraborty \& Hancz 2011; Ghasemi Pirbalouti, Jahanbazi, Enteshari, Malekpoor \& Hamedi 2010). The biological activity of WB has not yet been studied in fish. Moreover, the ability of herbal biomedicine on osmoregulation and stress response has not been studied seriously. Hence, this study was aimed to evaluate the effects of dietary inclusion of WB extract on some serum biochemical characteristics and stress responses in juvenile common carp, which has been exposed to handling and crowding stress.

\section{Materials and Methods}

\section{Fish}

Two hundred and fifty juvenile common carp (35 $\pm 5.2 \mathrm{~g}$ ) were obtained from Isfahan Fish Propagation and Breeding Center in summer 2012. The fish were kept under environmental condition, placed in $10 \mathrm{~m}^{3}$ rectangular concrete tanks for 2 weeks for acclimatisation. Then, they fed on a commercial carp feed (Isfahan Mokkamel, Iran) with proximate com- position (wet basis \%) as the following conditions: humidity $(9.2 \%)$, protein $(32 \%)$, lipid $(10.2 \%)$ and ash (11.1\%). These amounts were obtained based on our analyses (data not shown).

\section{Plant extract}

In spring 2012, the Wood betony aerial parts including flowers and leaves were collected from natural habitat, Isfahan province. The plants were delivered to the Central Herbarium of Isfahan University of Technology, Department of Natural Resources for final identification and analyses. Hydro-alcoholic plant extraction was done based on Ghasemi Pirbalouti et al. (2010) with some modification. Briefly, aerial parts of the plants were washed thoroughly with distilled water and dried at room temperature under shading. Then, the plants were grounded into powder. A $100 \mathrm{~g}$ of powdered plant material was soaked in $500 \mathrm{~mL}$ of ethanol (75\%) for $48 \mathrm{~h}$, shacked vigorously to allow for proper extraction. After filtering of the extract through Whatman paper no. 1, filtrate was concentrated using a rotary evaporator at $50{ }^{\circ} \mathrm{C}$. Finally, $20 \mathrm{~mL}$ of concentrated liquid extract was obtained from $100 \mathrm{~g}$ of the plant powder; each $\mathrm{mL}$ of the concentrated extract was almost equal to $5 \mathrm{~g}$ of the plant powder.

\section{Feed preparation and feeding trails}

In order to prepare the diets, the commercial pellet diet was crushed and mixed with the appropriate WB liquid extract concentration (the extract volumes were adjusted by adding distilled water to final volume of $100 \mathrm{~mL}$ for each $\mathrm{kg}$ of diet), remade into the pellets, were allowed to be dried for $72 \mathrm{~h}$ at room temperature and then stored at refrigerator until it was used. After 2 weeks of acclimatization, 180 individual fish $(44 \pm 0.62 \mathrm{~g})$ were randomly divided into four groups, with three replicate each. The first treatment was fed on normal diet without S. lavandulifolia and kept as control group. The second, third, and fourth ones were fed on normal diet containing 2, 4 and $8 \%$ of S. lavandulifolia, respectively (defined as $2 \mathrm{WB}, 4 \mathrm{WB}$ and $8 \mathrm{WB}$ ). Each replicate contained 15 individuals in a fibereglass tank (110 L water volume, 50\% renewed each day). 
Water quality was monitored throughout the experimental period at daily intervals; temperature $25 \pm$ $1{ }^{\circ} \mathrm{C}, \mathrm{pH} 7.21 \pm 0.5$ and dissolved oxygen concentration at $7.5 \pm 0.06 \mathrm{mg} \mathrm{L}^{-1}$. Fish were fed frequently on a diet of $32 \%$ crude protein $(\mathrm{CP})$ at a rate of $2 \%$ body weight, three times a day for 70 days.

\section{Stress challenge}

The stress challenge was performed according to Tahmasebi-Kohyani, Keyvanshokooh, Nematollahi, Mahmoudi \& Pasha-Zanoosi (2011) with some modifications. Briefly, at the end of 10 weeks, 30 fish from control and $8 \mathrm{WB}$ were subjected to stress challenge. For this purpose, the fish were remained on experimental diets and acclimatized for 1 week as defined before. After the acclimation period, three fish per tank were removed for sampling (time 0) prior to subjecting the remaining fish in the tank to an acute stress. The stress consisted of netting the remaining fish from the tank, holding them out of water for $5 \mathrm{~min}$, and then crowded at an approximate density of $150 \mathrm{~g} \mathrm{~L}^{-1}$ in a plastic mesh bucket in their original tank for $3 \mathrm{~h}$ without any aeration or water exchange. The experimental fish were sampled after $1 \mathrm{~h}$ of crowding, as they were released from the crowding stress ( $3 \mathrm{~h}$ ) and at 8,24 , and $48 \mathrm{~h}$.

\section{Blood sampling and biochemical analysis}

At the end of the 10-week experiment, for biochemical analyses, at least 3 fish from each replicate were anaesthetized with clove powder (100 ppm) and blood sampling (1.5-3 $\mathrm{mL}$ ) was performed individually from caudal puncture. The blood was centrifuged at $3000 \mathrm{rpm}$ for $10 \mathrm{~min}$ and the supernatant serum was collected. The serum was kept frozen at $-80{ }^{\circ} \mathrm{C}$ until analyses for enzymatic activity of lactate dehydrogenase (LDH), aspartate transaminase (AST), alkaline phosphatise (ALP), and alanine transaminase (ALT) activities (Peyghan \& Azary Takamy 2002).

To evaluate the stress response of the fish, they were captured with minimal disturbance at the time described above (stress challenge). Cortisol and glucose levels were determined using radioimmunoassay method (Immunotech, France) and colorimetric glucose oxidize procedure (Benfey \& Biron 2000). The ions levels were assayed based on Braun, Lima, Baldisserotto, Dafre \& Nuner (2010).

\section{Statistical analysis}

Statistical analysis was performed by one way ANOVA at 5\% significant level. A multiple comparison test (Duncan multiple range test, DMRT) was conducted to compare the statistically significant differences among the groups using SPSS Version19. Values were presented as mean \pm standard errors. To evaluate the differences between stress related analysed parameters at the same time between two experimented groups, paried T-test was utilized.

\section{Results}

At the end of the experiment (10 weeks), levels of serum ALP and AST did not change significantly among groups $(\mathrm{P}>0.05)$. LDH showed significant decrease in group of fish fed on $8 \%$ WB $(256.25$ $\left.\pm 40.30 \mathrm{UL}^{-1}\right)$ compared to control group (605.5 \pm $78.98 \mathrm{UL}^{-1}$ ) plus other groups treatments (Table 1; $\mathrm{P}<0.05$ ).

The levels of ALT were in the range of 3.5-8.25 $\mathrm{UL}^{-1}$ (Table 1). Inclusion of WB in the diet, higher than $2 \%$ could decline ALT level significantly (Table $1 ; \mathrm{P}<0.05$ ). Regarding the stress challenges, the fish treated by control diet had an initial cortisol level of $9.23 \mathrm{ng} \mathrm{mL}^{-1}$ which rose significantly to 27 $\mathrm{ng} \mathrm{mL}-1$ at $1 \mathrm{~h}$ and reduced to $16 \mathrm{ng} \mathrm{mL}^{-1}$ at $3 \mathrm{~h}$ and remained in a plateau state without any significant changes until $48 \mathrm{~h}$ (Fig. 1).

The fish fed on $8 \%$ WB had an initial cortisol level at $6.53 \mathrm{ng} \mathrm{mL}^{-1}$ which increased significantly to 18.66 $\mathrm{ng} \mathrm{mL}-1$ after $1 \mathrm{~h}$ and then reduced to $12.2 \mathrm{ng} \mathrm{mL}^{-1}$ which were similar to basal level after $8 \mathrm{~h}$ (Fig. 1). Cortisol level showed very limited changes during $8-48 \mathrm{~h}$ post stress in $8 \mathrm{WB}$ group (Fig. 1). In general, the hormone levels were higher in fish fed control diet than that of $8 \%$ WB (Fig. 1). However, only significant differences were observed $1 \mathrm{~h}$ and $8 \mathrm{~h}$ post-stress (Fig. 1; $\mathrm{P}<0.05$ ). Glucose concentrations in fish fed control diet were $62.66 \mathrm{mg} \mathrm{dL}^{-1}$ which significantly rose up to 157 and $264 \mathrm{mg} \mathrm{dL}^{-1}$ at $1 \mathrm{~h}$ and 3 h, respectively (Fig. 2; $\mathrm{P}<0.05$ ). 


\section{S Bahrami Babaheydari et al., Effect of wood betony extract on stress response in carp}

Table 1 Serum enzymes (UL) in common carp fed different levels of dietary wood betony extract for 10 weeks

\begin{tabular}{lllll}
\hline Variable $\left(\mathrm{U} / \mathrm{L}^{-1}\right)^{*}$ & Control $(0)$ & $2 \%$ & $4 \%$ & $8 \%$ \\
\hline ALP & $87.75 \pm 6.68^{\mathrm{a}}$ & $81.75 \pm 11.23^{\mathrm{a}}$ & $80.50 \pm 6.68^{\mathrm{a}}$ & $78.50 \pm 1.19^{\mathrm{a}}$ \\
AST & $178.00 \pm 51.96^{\mathrm{a}}$ & $115.00 \pm 35.12^{\mathrm{a}}$ & $114.50 \pm 17.93^{\mathrm{a}}$ & $70.75 \pm 11.98^{\mathrm{a}}$ \\
LDH & $605.50 \pm 78.98^{\mathrm{a}}$ & $580.25 \pm 106.08^{\mathrm{a}}$ & $557.00 \pm 102.10^{\mathrm{a}}$ & $256.25 \pm 40.30^{\mathrm{b}}$ \\
ALT & $8.25 \pm 1.60^{\mathrm{a}}$ & $6.75 \pm 0.75^{\mathrm{ab}}$ & $4.75 \pm 0.85^{\mathrm{bc}}$ & $3.50 \pm 0.28^{\mathrm{c}}$ \\
\hline
\end{tabular}

Alkaline phosphatase, ALP; asparate transaminase, ASP; lactate dehydrogenase, LDH and alanine transaminase, ALT. Values are mean \pm SEM. Mean values with different superscripts are significantly different from each other $(\mathrm{P}<0.05)$.

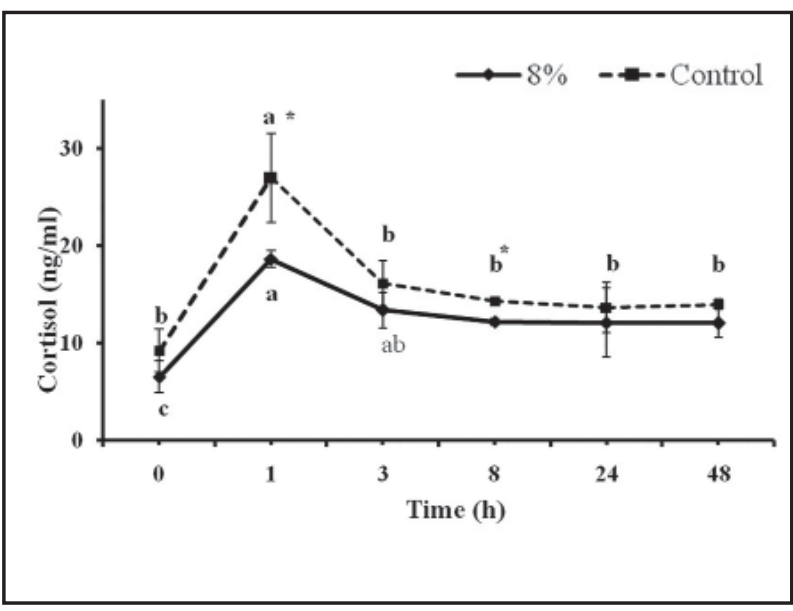

Figure 1 Serum cortisol $\left(\mathrm{ng} \mathrm{mL}^{-1}\right)$ levels of common carp subjected to acute handling followed by $3 \mathrm{~h}$ of crowding stress in fish fed the control and $8 \%$ diets. Data are presented as mean \pm standard error as error bars; Significant differences between different time of blood sampling in the same group $(\mathrm{P}<0.05$; Duncan test) or between two groups ( 0 and $8 \%$ of WB) at the same time $(\mathrm{P}<0.05$; t-test $)$ are indicated by unlike letters, and *,respectively.

As Figure 1 illustrates, the glucose level did not return to the basal level until $48 \mathrm{~h}$ post-stress $(\mathrm{P}<0.05)$. In fish treated with $8 \% \mathrm{WB}$, the initial glucose level was reported as $59.33 \mathrm{mg} \mathrm{dL}^{-1}$, that is very similar to those which have been measured in control group (Fig. 1; P>0.05). The glucose concentration was elevated in a very gradual route and reached to 96 and $146.66 \mathrm{mg} \mathrm{dL}^{-1}$ at 1 and $3 \mathrm{~h}$ post-stress, respectively (Fig. 1). Similar to those reported for control group, the glucose level for $8 \mathrm{WB}$ fish did not changed significantly during $3 \mathrm{~h}$ to $48 \mathrm{~h}$ (Fig. 1 ; $\mathrm{P}>0.05$ ). At all intervals, the glucose levels were higher in control group compared to $8 \mathrm{WB}$, but significant differences were only observed at 1,3 and $8 \mathrm{~h}$ post-stress (Fig. 2; $\mathrm{P}<0.05$ ). At both treatments prior to stress induction, serum sodium concentrations were 156 mmol L-1 in fish. In control group, the sodium level dropped to the lowest level at $3 \mathrm{~h}$, then elevated to initial level throughout the experiment (Fig. 3A).

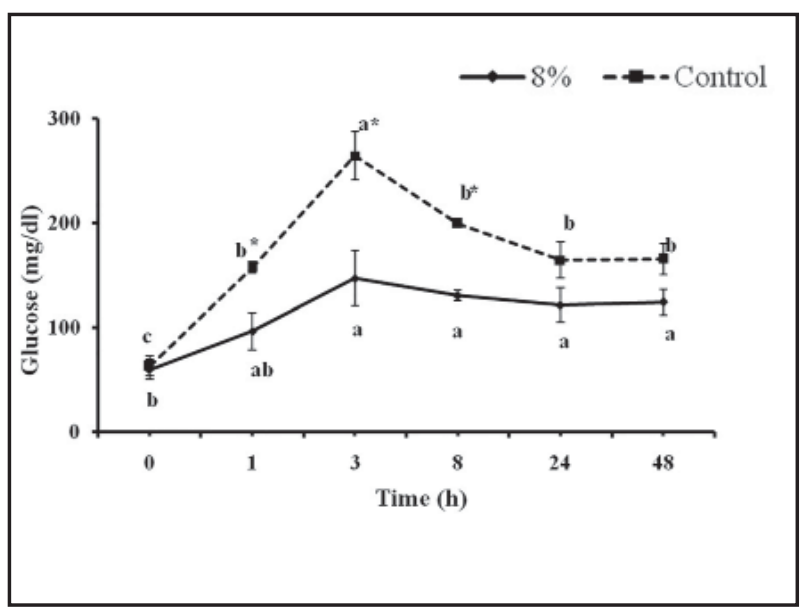

Figure 2 Serum glucose $\left(\mathrm{mg} \mathrm{dL}^{-1}\right)$ levels of Common carp subjected to acute handling followed by $3 \mathrm{~h}$ of crowding stress in fish fed the control and $8 \%$ diets. Data are presented as mean \pm standard error as error bars; Significant differences between different time of blood sampling in the same group $(\mathrm{P}<0.05$; Duncan test) or between two groups ( 0 and $8 \%$ of WB) at the same time $(\mathrm{P}<0.05 ; \mathrm{t}$-test $)$ are indicated by unlike letters and $*$, respectively.

In fish fed on $8 \% \mathrm{WB}$, the sodium level did not change significantly during the experiment (time 0 to 48h; Fig. 3A; P > 0.05). In all sampling times, the sodium levels in fish fed on $8 \%$ WB were higher than those of measured in control group (Fig. 3A), but these differences were insignificant (Fig. 3A; $\mathrm{P}>0.05$ ). For control group, the potassium and calcium levels were in the range of $0.53-0.73$ and 2.55$3 \mathrm{mmol} / \mathrm{L}$, respectively and did not show any significant differences during the sampling time (Fig. 3B, C; P > 0.05). Similar to the control group, the concentration of potassium and calcium levels were too low, that is, in the range of 0.6-1 and 2.81-2.94 $\mathrm{mmol} / \mathrm{L}$, respectively. The concentrations of these ions did not change throughout the experiment (Fig. $3 \mathrm{~B}, \mathrm{C} ; \mathrm{P}>0.05)$. At the most sampling time, the potassium and calcium levels for fish fed on $8 \mathrm{WB}$ were higher than those measured for control fish (Fig. 3B, C) without any significant differences 


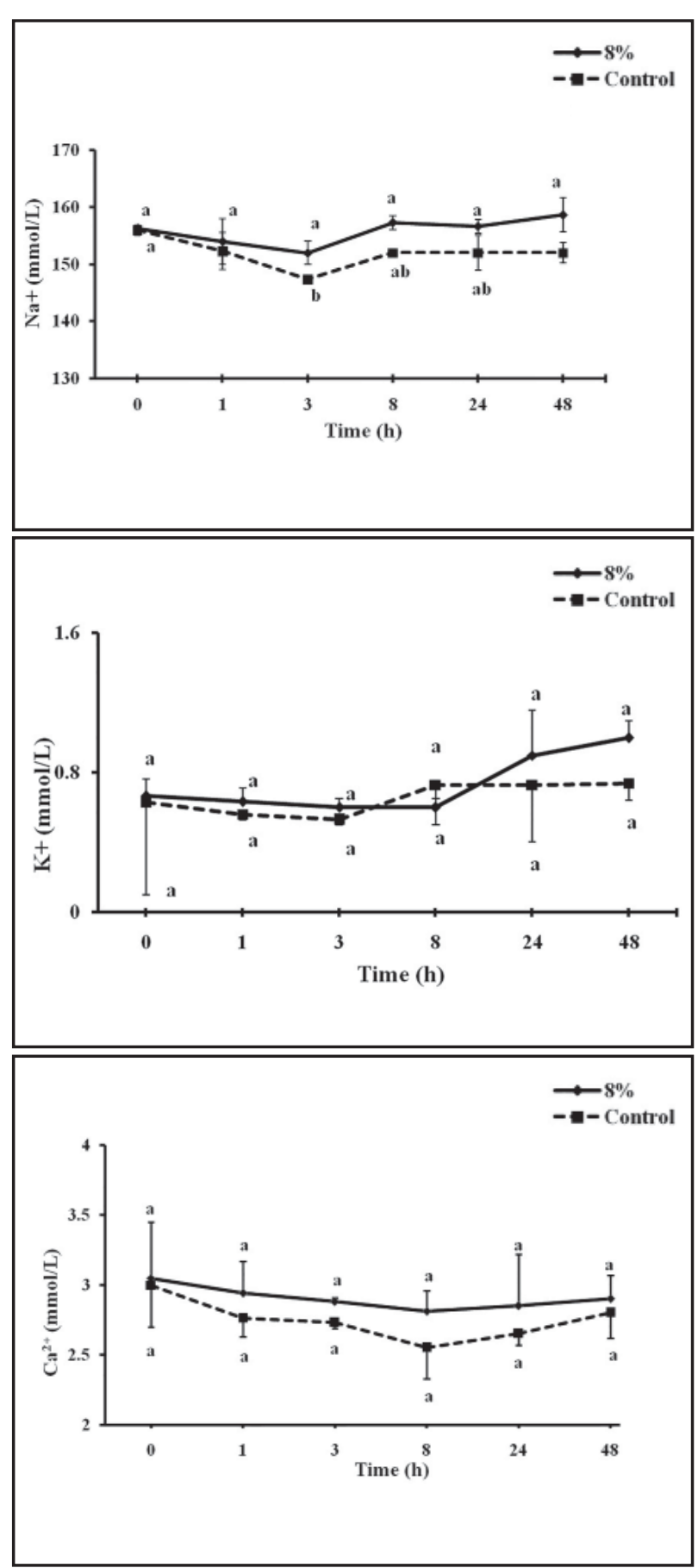

Figure 3 The effects of dietary wood betony extract on some ion concentrations $\mathrm{Na}+(\mathrm{A}), \mathrm{K}+(\mathrm{B})$ and $\mathrm{Ca}++(\mathrm{C})$ in common carp exposed to acute handling followed by $3 \mathrm{~h}$ of crowding stress. Data are presented as mean \pm standard error as error bars; Significant differences between different time of blood sampling in the same group $(\mathrm{P}<0.05$; Duncan test $)$ is indicated by unlike letters.

(Fig. 3B, C; P > 0.05).

\section{Discussion}

Many research works have been conducted on the use of different herbal medicines in aquaculture both in finfish (Chakraborty \& Hancz 2011) and shellfish species (Citarasu 2010). Despite many studies have been investigated the effects of dietary phytochemical on growth or immunity parameters, less information is available about the use of these environmental friendly compounds such as anti-stress agent in aquaculture industry. Different stressors can influence hypothalamus- pituitary- internal axis of the aquatics, mainly fish like other vertebrates and impact on dynamic balance of organisms. In this study, at least the level of two serum enzymes including LDH and ALT were significantly reduced by inclusion of $8 \% \mathrm{WB}$ in the diet of carp. Also fish fed with $2 \%$ and $4 \% \mathrm{WB}$ had a tendency of decrease in these enzymes. None significant decreasing pattern was also reported for ALP and AST by elevating the WB in the diet. Although mentioned enzymes have been obtained in different tissues such as heart, skeletal muscle and kidneys in vertebrates, liver usually considered as a main source of these enzymes. Also, the elevation of these enzymes in fish serum, in response to exogenous compounds such as food additive and heavy metals, may be considered as an indication for liver dysfunction (Talas \& Gulhan 2009). The decline of some serum enzyme at least in groups received the highest dose of WB could explain potential benefit of wood betony for fish welfare by improving liver function. Recently, Y11maz, Ergün \& Çelik (2013) revealed the positive effects of dietary thyme (Thymus vulgaris), rosemary (Rosmarinus officinalis) and fenugreek (Trigonella foenum graecum) on some physiological characteristics of sea bass (Dicentrarchus labrax). The fish fed on these medicinal herbal extracts had better liver function, which has been evaluated as lower total liver fat, visceral fat index and hepatosomatic index (HSI). Some researchers (e.g., Cho, Lee, Park, Ji, Lee, Bae \& Oh 2007; Zheng, Tan, Liu, Zhou, Xiang \& Wang 2009) conducted experiments with channel catfish, Ictalurus punctatus, fed a basal diet containing Greek oregano, Origanum heracleoticum essential oil and olive flounder, Paralichthys olivaceus, fed diets supplemented with green tea, Camellia sinensis, respectively and showed signifi- 


\section{S Bahrami Babaheydari et al., Effect of wood betony extract on stress response in carp}

cant improvement in the fish liver function. Furthermore, Srinivasan (2005) reported different active compounds of herbs stimulated digestion, accompanied by enhanced bile acid concentration, stimulated the pancreas, and increased the secretion of digestive enzyme activities in chicken broilers. It is possible that different antioxidant compounds available in the wood betony extract can influence liver function in fish. Franki ${ }^{2}$, Volj ${ }^{2}$ c, Salobir \& Rezar (2009) reported that antioxidants enhance the synthesis of bile acids in the liver; However, due to the limited scientific data about the effect of herbal biomedicine on liver enzyme activity (Xie et al. 2008), more research is needed to expand our knowledge concerning the physiological mechanisms of fish phenomenon.

It is well-documented that fish like other vertebrate try to cope stress by changing some biochemical compositions such as blood cortisol, glucose as well as different ions (Fevolden \& Roed 1993; Barton 2002). Cortisol elevation usually considered as a first smart signal for fish under stress (Hsieh, Chen \& Kuo 2003). The blood cortisol level of common carp was as low as $10-20 \mathrm{ng} \mathrm{mL}^{-1}$ before stress challenge, abruptly increased just $1 \mathrm{~h}$ after stress exposure, and the sharply decreased to basal level at 3 or $8 \mathrm{~h}$. Regardless, the pattern of the hormone changes, the blood cortisol levels of fish fed on $8 \%$ WB apparently reported lower than the control group in the most time intervals. This indicates that WB can mitigate cortisol charge, which is motivated by handing stress. These findings are in conformity with the report of Xie et al. (2008) on common carp. Blood glucose elevations imply to stress usually considered as atypical secondary stress response (Barton \& Iwama 1991). Usually, the major reason for blood glucose rise is dissimilation and dissolution of liver glycogen for providing energy during stress process, caused by elevation of different hormone level, especially in cortisol (Hsieh et al. 2003). The current study indicated that blood glucose levels increased significantly after stress and reached the highest concentration at $3 \mathrm{~h}$; $2 \mathrm{~h}$ after highest level of blood cortisol level. Nonetheless, the augmentation of blood sugar in fish fed on $8 \% \mathrm{WB}$ was much lower than control group indicating that WB could also assuage blood glucose load probably because of the hormone diminish. Significant reduction in serum glucose levels were also reported for Tilapia (Oreochromis mossambicus) fed on diet supplemented from four different medicinal plant (Immanuel et al. 2009) and common carp received diet containing rhubarb (Rheum officinale) extract (Xie et al. 2008). Ion concentrations could be used deliberately as a useful tool to evaluate secondary stress response in fish. It is under control of several neuroendocrine pathways in fish which some of them are similar to those affect stress responses. It is well understood that releasing cathecholamines and cortisol can modify ion regulations (McCormick 2001). In this study, the ion concentration level leaved unaffected in both control and 8WB all tested interval. However, the only exception was lower sodium concentration of the control fish at $3 \mathrm{~h}$ in comparison to time zero which may show some positive effects of dietary WB on sodium regulation in common carp. Nevertheless, the ion disturbance in fish, after stress exposure, has been influenced by several factors such as type of stress, stress intensity, duration, and fish species (Barton 2002; Tejpal, Pal, Sahu, Kumar, Muthappa, Vidya \& Rajan 2009). Based on our knowledge, the effects of dietary phytochemical on ion regulatory capacity of fish are poorly understood (Immanuel et al. 2009) and further research is needed in order to find out the exact mechanisms.

In conclusion, the findings of this study indicated that a dietary addition of wood betony could improve some of the physiological conditions of common carp. Thus, this study provides a new perspective for the use of medicinal herbs, which can be added to fish feed literature. Wood betony containing a number of different active components, which possibly play an important role in improving organ function and stress responses. However, the mechanism by which this occurs needs further and more detailed research.

\section{Acknowledgements}

The authors would like to thank to Isfahan Aquatic 
Propagation and Breeding Center for supplying fish. This research was supported with funding from the Isfahan University of Technology under grant number 502.90 .53949 awarded by Dr. Salar Dorafshan. We also thank Dr. Yazdan Keivany for reviewing the manuscript.

\section{References}

Alishahi M., Ranjbar M.M. \& Ghorbanpour M. (2010) Effects of dietary Aloe vera on some specific and nonspecific immunity in the common carp (Cyprinus carpio). International Journal of Veterinary Research 4, 189-195.

Barton B.A. (2002) Stress in fish: a diversity of responses with particular reference to changes in circulating corticosteroids. Integrative and Comparative Biology 42, 517525.

Barton B.A. \& Iwama G.K. (1991) Physiological changes in fish from stress in aquaculture with emphasis on the response and effects of corticosteroids. Annual Review in Fish Disease 1, 3-26.

Benfey T.J. \& Biron M. (2000) Acute stress response in triploid rainbow trout (Oncorhynchus mykiss) and brook trout (Salvelinus fontinalis). Aquaculture 184, 67-76.

Braun N., Lima R.L.D., Baldisserotto B., Dafre A.L. \& Nuner A.P.O. (2010) Growth, biochemical and physiological responses of Salminus brasiliensis with different stocking densities and handling. Aquaculture 301, 22-30.

Citarasu T. (2010) Herbal biomedicines: A new opportunity to aquaculture industry. Aquaculture International 18, 403-414.

Chakraborty S.B. \& Hancz C. (2011) Application of phytochemicals as immunostimulant, antipathogenic and antistress agents in finfish culture. Review in Aquaculture 3, 103-119.

Cho S.H., Lee S.M., Park B.H., Ji S.C., Lee J., Bae J. \& Oh. S.Y. (2007) Effect of dietary inclusion of various sources of green tea on growth, body composition and blood chemistry of the juvenile Olive Flounder, Paralichthys olivaceus.
Fish Physiology and Biochemistry 33, 49-57.

Cho S.H. \& Lee S.M. (2012) Onion powder in the diet of the Olive flounder, Paralichthys olivaceus: effects on the growth, body composition, and lysozyme activity. Journal of World Aquaculture Society 43, 30-38.

Dada A.A. \& Ikuerowo M. (2009) Effects of ethanolic extracts of Garcinia kola seeds on growth and haematology of catfish (Clarias gariepinus) broodstock. African Journal of Agricultural Research 4, 344-347.

Dobšikova R., Svobodova Z., Blahova J., Modra H. \& Velišek J. (2006) Stress response to long distance transportation of common carp (Cyprinus carpio L.). Acta Veterinaria Brno 75, 437-448.

Fevolden S.E. \& Roed K.H. (1993) Cortisol and immune characteristics in rainbow trout (Oncorhynchus mykiss) selected for high or low tolerance to stress. Journal of Fish Biology 54, 900-910.

Frankic T., Voljc M., Salobir J. \& Rezar V. (2009) Use of herbs and spices and their extracts in animal nutrition. Acta Agriculturae Slovenica 94, 95-102.

Ghasemi Pirbalouti A., Jahanbazi P., Enteshari S., Malekpoor F. \& Hamedi B. (2010) Antimicrobial activity of some of the Iranian medicinal plants. Archives of Biological Science Belgrade 62, 633-642.

Hsieh S.L., Chen Y.N. \& Kuo C.M. (2003) Physiological responses, desaturase activity and fatty acid composition in milkfish (Chanos chanos) under cold acclimation. Aquaculture 220, 903-918.

Immanuel G., Uma P.R. \& Iyapparaj P. (2009) Dietary medicinal plant extracts improves growth, immune activity and survival of tilapia (Oreochromis mossambicus). Journal of Fish Biology 74, 1462-1475.

Javidnia K., Mojab F. \& Mojahedic A. (2004) Chemical constituents of the essential oil of Stachys lavandulifolia Vahl from Iran. Journal of Pharmacy Research 3, 61-63. 


\section{S Bahrami Babaheydari et al., Effect of wood betony extract on stress response in carp}

McCormick S.D., Shrimpton J.M., Carey J.B., O’Dea M.F., Sloan K.E., Moriyama S. \& Björnsson B.Th. (1998) Repeated acute stress reduces growth rate of Atlantic salmon parr and alters plasma levels of growth hormone, insulin-like growth factor I and cortisol. Aquaculture 168, 221-235.

McCormick S.D. (2001) Endocrine control of osmoregulation in teleost fish. American Zoology 41, 781-794.

Ody P. (1997) The complete medicinal herbal, a practical guide to medicinal herbs, with remedies for common ailments. Dorling Kindersley Publication, London, Great Britain.

Pakravan S., Hajimoradloo A. \& Ghorbani R. (2012) Effect of dietary willow herb Epilobium hirsutum extract on growth performance, body composition, haematological parameters and Aeromonas hydrophila challenge on common carp, Cyprinus carpio. Aquaculture Research 43, 861-869.

Peyghan R. \& Azary Takamy G. (2002) Histopathological, serum enzyme, cholesterol and urea changes in experimental acute toxicity of ammonia in common carp (Cyprinus carpio) and use of natural zeolite for prevention. Aquaculture International 10, 317-325.

Rezazadeh S.H., Zaringhalam J., Manaheji H. \& Kebryaeezadeh A. (2009) Anti-inflammatory and anti-hyperalgesic activities of Stachys athorecalyx extracts on CFA-induced inflammation. Journal of Medicinal Plant Research 3, 368-376.

Shahsavani D., Baghshani H. \& Alishahi E. (2010) Efficacy of allicin in decreasing lead $(\mathrm{Pb})$ accumulation in selected tissues of lead-exposed common carp (Cyprinus carpio). Biological Trace Element Research 142, 572-580.

Soosean C., Marimuthu K. \& Sudhakaran S. (2010) Effects of mangosteen (Garcinia mangostana L.) extract as a feed additive on growth and haematological parameters of African catfish (Clarias gariepinus) fingerlings. European Review for Medical and Pharmacological Sciences 14,
605-611.

Srinivasan K. (2005) Spices as influencers of body metabolism: an overview of three decades of research. Food Research International 38, 77-86.

Tahmasebi-Kohyani A., Keyvanshokooh S., Nematollahi A., Mahmoudi N. \& Pasha-Zanoosi H. (2011) Dietary administration of nucleotides to enhance growth, humoral immune responses, and disease resistance of the rainbow trout, Oncorhynchus mykiss fingerlings. Fish and Shellfish Immunology 30, 189-193.

Talas Z.S. \& Gulhan M.F. (2009) Effects of various propolis concentrations on biochemical and hematological parameters of rainbow trout (Oncorhynchus mykiss). Ecotoxicology and Environmental Safety 72, 1994-1998.

Tejpal C.S., Pal A.K., Sahu N.P., Kumar J.A., Muthappa N.A., Vidya S. \& Rajan M.G. (2009) Dietary supplementation of L-tryptophan mitigates crowding stress and augments the growth in Cirrhinus mrigala fingerlings. Aquaculture 293, 272-277.

Urbinati E.C. \& Carneiro P.C.F. (2001) Metabolic and hormonal responses of matrinxa, Brycon cephalus, (Teleost: Characidae) to transport stress under influence of benzocaine. Journal of Aquaculture in the Tropics 16, 7585.

Vundac V.B., Brantner A.H. \& Plazibat M. (2007) Content of polyphenolic constituents and antioxidant activity of some Stachys taxa. Food Chemistry 104, 1277-1281.

Xie J., Liu B., Zhou Q., Su Y., He Y., Pan L., Ge X. \& Xu P. (2008) Effects of anthraquione extract from rhubarb Rheum officinale Bail on crowding stress response and growth of common carp Cyprinus carpio var. Jian Sheng. Aquaculture 281, 5-11.

Yllmaz S., Ergün S. \& Çelik E.S. (2013) Effect of dietary herbal supplements on some physiological conditions of sea bass Dicentrarchus labrax. Journal of Aquatic Animal Health 25, 98-103. 
Zheng Z.L., Tan J.Y.W., Liu H.Y., Zhou X.H., Xiang X. \& Wang K.Y. (2009) Evaluation of oregano essential oil (Origanum heracleoticum L.) on growth, antioxidant effect and resistance against Aeromonas hydrophila in Channel Catfish (Ictalurus punctatus). Aquaculture 292, 214-218. 


\title{
اثر عصاره جاى كوهى (Stachys lavandulifolia) بر برخى بارامترهاى بيوشيميايى سرم و باسخ به استرس حاد در كيور معمولى (Cyprinus carpio) جوان يران
}

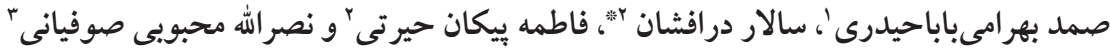

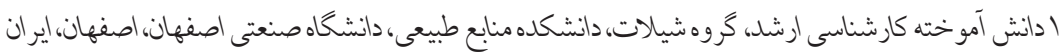

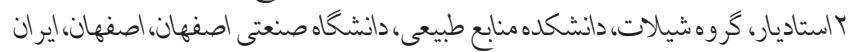

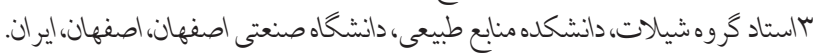

تاثير جهار سطح مختلف عصاره خاى كوهى (Stachys lavandulifolia) شامل •، ז، أو ^ درصد در جيره بر سطح برخى آنزيمهاى سرمىو

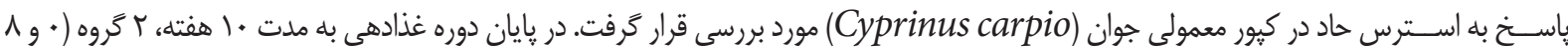

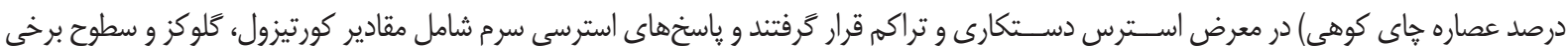
الكتروليتها (

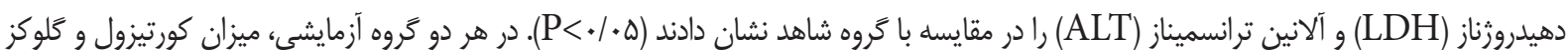

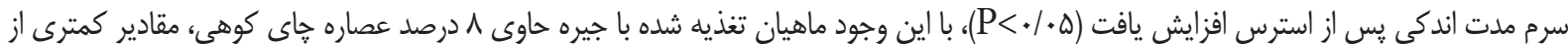

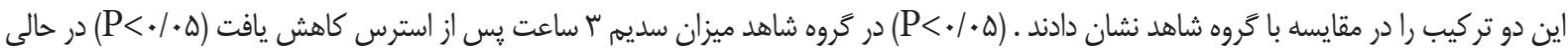

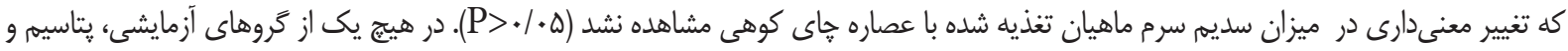

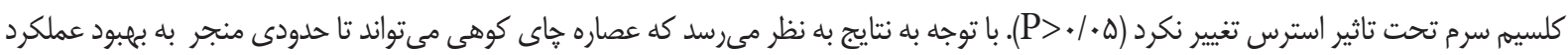
كبد و پاسخ به استرس در ماهيان جوان كيور معمولى شود. وازههاى كليدى: استرس، فعاليت آنزيمى، تنظيم يونى، جاى كوهى، كيور معمولى. sdorafshan@cc.iut.ac.ir : :ويسنده مسئول* 